This is the 'post-print' version (accepted following the referee process) of this paper in accordance with the Green Access standard for this journal

\title{
Structural indicators of spider communities across the forest plantation cycle
}

This paper has been published in the Journal of Forest Ecology and Management,

Volume 212 (2005) 171 - 183 


\begin{abstract}
Given the expansion of plantation forests in Ireland over recent years, there is a need to assess their impact on biodiversity and to identify how sustainable forest management strategies can incorporate biodiversity. We aimed to assess the impact of plantation forests on spider communities and identify structural indicators of their diversity. Pitfall traps were used to sample spiders in Sitka spruce (Picea sitchensis) and ash (Fraxinus excelsior) plantations at different stages of the forest cycle and cover of vegetation, dead wood and soil organic content were measured within each site. Ordinations revealed that spider assemblages were separated by both forest development and canopy species across the forest cycle. The pre-thicket ash and spruce assemblages were similar, whereas canopy species had a greater effect in the more structurally developed stands. The mature ash plots formed a distinct group from the other stands. Overall species richness was highest in the spruce and ash pre-thicket stands, and in the mature spruce stands with a more open canopy. Mature ash stands had the lowest species richness. Lower field layer vegetation was positively correlated with total spider species richness and open habitat specialist species richness whereas canopy closure had a negative effect on these species variables. Forest spider species were positively correlated with litter cover, depth and twig cover. To enhance the diversity of open and forest spider species within a stand, the growth of lower field layer vegetation should be encouraged at all stages of the forest cycle, whilst retaining features typical of a mature forest. Within a plantation, a mosaic of different aged stands will sustain both open and forest specialists to enhance diversity. The distinct assemblages found in the mature plantations indicate that on a landscape scale, the establishment of both ash and spruce plantations will enhance overall diversity.
\end{abstract}




\section{Introduction}

Sustainable forest management is now a priority for governments and forest agencies worldwide. In this context recent research has centred on various aspects of biodiversity and its conservation in forested habitats, from plants (Humphrey et al., 2002), to birds (Haila et al., 1994) and invertebrates (Pettersson, 1996; Jukes et al., 2001). However more focused research is essential for sustainable forest management, specifically to answer the following questions: What aspects of biodiversity can be effectively targeted for sustainable forest management? and, how can this be implemented on a large scale, e.g. at a national level.

Full inventory studies in even the simplest of habitats require more time, expertise and resources than most research/forest agencies can reasonably provide. This has led to a focus on indicators of biodiversity, especially in the implementation of sustainable forest management strategies (Noss, 1990; Ferris \& Humphrey, 1999; Humphrey et al., 1999; Ferris et al., 2000).

In the past biodiversity and conservation studies have concentrated on the larger, more charismatic 'flagship' taxa such as mammals, birds and butterflies. Recent research has paid more attention to incorporating the requirements of invertebrates into forest management strategies (Humphrey et al., 1999; Oliver et al., 2000) such as for carabid beetles, spiders and hoverflies (Butterfield et al., 1995; Humphrey et al., 1999; De Bakker et al., 2000; Jukes et al., 2001; Willett, 2001).

Spiders are abundant in most terrestrial ecosystems (Uetz, 1991). They are primarily affected by change in vegetation structure (Uetz, 1991), and this has led to their use in studies of habitat and the effects of disturbance (Uetz, 1979; Downie et al., 1996; Marc et al., 1999; Huhta, 2002). They also have the advantage of being efficiently sampled and relatively easily identified compared to other invertebrate groups.

There is much current interest in the use of spiders as biodiversity indicators (Marc et al., 1999; Gravesen, 2000). Spiders occupy a strategic functional position in terrestrial food webs: they are important in the regulation of invertebrate populations and as a food source for higher organisms. Ferris and Humphrey (1999) assert that indicators can be of greatest use when they are of functional importance 
in ecosystems, that is, they have numerous direct and indirect relationships with other taxa. Thus spiders may be of use as surrogate indicators of diversity for other invertebrate groups. Spider communities are ubiquitous in forest ecosystems, being present from the litter layers to the canopy (Uetz, 1979, Halaj et al., 2000), and hence are ideal for study in forest environments. However their ability to illustrate ecosystem change and their potential as surrogate indicators also warrants their further investigation.

The overall objective of our study was to contribute to the development of forestry management for biodiversity in Ireland. McGeoch (1998) suggested a framework of nine steps in the selection of potential biodiversity indicators for terrestrial invertebrates and these have been summarised into three main steps by Duelli and Obrist (2003). Firstly, the particular element of biodiversity (i.e. species richness or assemblage structure of a target group or species) must be defined in a quantifiable way. Secondly, the target element of biodiversity should be surveyed with adequate statistical replication. Thirdly, the relationship between potential biodiversity indicators and the target element of biodiversity should be investigated.

Based on these criteria the aims of the present study are:

1) To identify how spider communities change over the forest cycle and differ between plantation types.

Currently in Ireland $9.8 \%$ of the land is forested, of which $90 \%$ is plantation forests (Fahy \& Foley, 2002). Little is known of the flora and fauna of Irish plantations, especially regarding the invertebrate species present (Fahy \& Gormally, 1998).

2) To identify potential structural indicators of spider diversity.

Compositional indicators (i.e. genetic, population and community diversity) and functional indicators (i.e. ecosystem processes) (See Noss, 1990 for further details) often require specialised taxonomic or technical knowledge for their identification and implementation as indicators. Structural indicators (i.e. habitat variables correlated with a target taxonomic group), however, have the potential to produce a suite of more easily identifiable indicators. 
3) To assess if different structural indicators can be identified during the various stages of the forest plantation cycle.

It is likely that during the various stages of forest development the composition of spider communities will change and this may be reflected in the variety of potential biodiversity indicators identified. For example the spider communities which are found in the early stages of forest development may not be influenced by the same environmental variables as those in the more mature forests, which are likely to have a greater number of forest specialists. 


\section{Methodology}

Study sites

Sitka spruce (Picea sitchensis) and ash (Fraxinus excelsior) were chosen as the canopy species because they are widely planted in Ireland (Forest Service, 2000), with spruce comprising $59.5 \%$ of all the grant-aided afforestation and ash $43 \%$ of all broadleaves planted in 2000 (Joyce \& O' Carroll, 2002). Potential sites were identified using the forest inventory database of Coillte Teoranta and were matched for soil, altitude, pre-planting habitat type, size of plantation, age, management regime. The final sites were selected following extensive site visits and included sites with easy access, those typical of forest development in relation to their planting age and where possible were grouped into geographical clusters.

Study sites were located across Ireland (0). Four age classes were selected to represent the various stages of the forest cycle: 5 year old stands (4 replicate sites of each canopy species); 8-15 year stands (8 replicates of each canopy species), 20-30 year stands (4 replicates of spruce only) and commercial maturity which was classified as 35-50 years (8 replicates of spruce and 4 replicates of ash) and $>50$ years for ash (4 replicates of ash). For further information on the various physical attributes of each site and details of site selection see Gittings et al. (2004). 


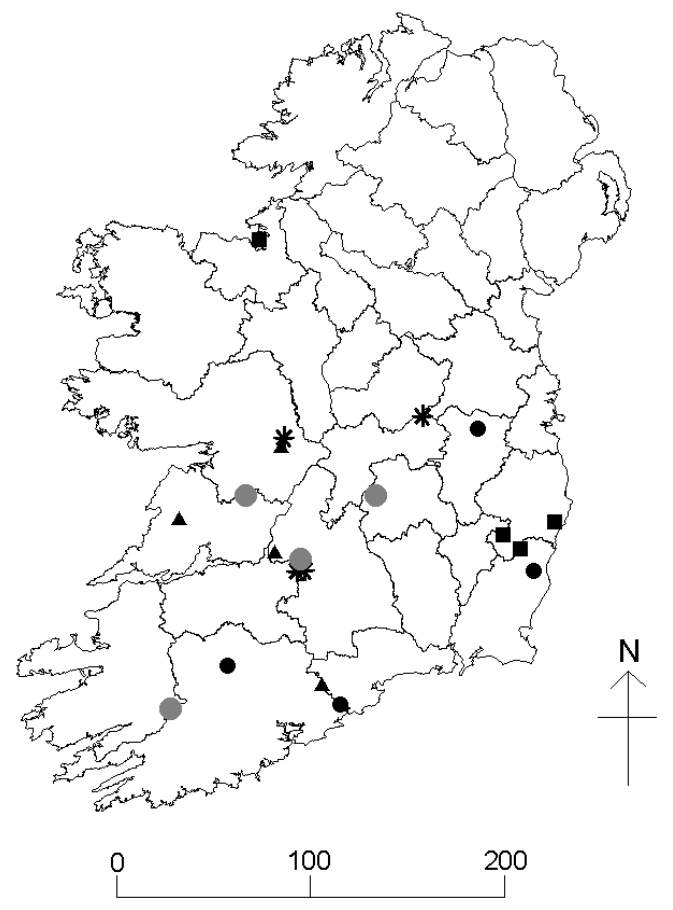

Figure 1. Map of Ireland showing the geographical location of the sites. $\%=5$ year old Sitka spruce and ash; $\#=50+$ year old ash; $!=35-40$ year old Sitka spruce; $\#=$ Cluster of 8-15 year old spruce and ash, 20-30 year spruce and 35-50 year spruce and ash; $*=8-15$ year old ash. 
Preliminary site visits indicated that stands with similar planting ages sometimes differed structurally in forest development, probably due to variations in environmental factors such as soil type or drainage as well as forest management practices. This has been noted in other studies which utilise forest structural development rather than age (Ferris et al., 2000; Jukes et al., 2001; Humphrey et al., 2002). Ward's hierarchical clustering was used (Legendre \& Legendre, 1998) to reclassify the plots (see below) on the basis of their structural properties in order to give a more accurate picture of the forest cycle. The following parameters were used: percentage canopy cover, tree height, mean diameter at breast height and minimum distance between trees which identified five structural classes in both ash and spruce (0). These were all allocated at the plot level (rather than site level), as structural variation within sites was sometimes considerable. 
Table 1 Structural parameters used to determine the allocation of ash and Sitka spruce plots into various structural groups. Mean values (and range in brackets) are shown ( $\mathrm{n}=$ number of plots). Data adapted from Gittings et al. (2004).

\begin{tabular}{lcccc}
\hline Structural group & Canopy cover $(\%)$ & Tree height $(\mathrm{m})$ & DBH $(\mathrm{cm})$ & $\begin{array}{c}\text { Min. distance } \\
\text { between trees }(\mathrm{m})\end{array}$ \\
\hline Pre-thicket spruce $(\mathrm{n}=21)$ & $29.6(11.7-43.3)$ & $2.5(1.4-3.8)$ & $3.7(1.6-7.0)$ & $1.6(1.0-2.0)$ \\
Thicket spruce $(\mathrm{n}=29)$ & $80.3(60.0-93.3)$ & $5.9(4.3-7.3)$ & $12.4(10.4-16.5)$ & $1.9(1.5-2.0)$ \\
Closed-maturing spruce $(\mathrm{n}=35)$ & $86.9(78.3-95.0)$ & $12.7(9.8-15.7)$ & $19.3(10.4-16.5)$ & $1.7(1.4-2.0)$ \\
Reopening spruce $(\mathrm{n}=10)$ & $70.8(63.3-80.0)$ & $18.8(16.8-20.0)$ & $22.4(21.0-24.8)$ & $2.3(2.0-2.8)$ \\
Mature spruce $(\mathrm{n}=25)$ & $54.7(40.0-60.0)$ & $21.1(18.3-23.0)$ & $39.0(31.6-44.8)$ & $3.9(3.0-6.0)$ \\
Pre-thicket ash $(\mathrm{n}=24)$ & $12.2(5.0-21.7)$ & $3.1(1.3-5.0)$ & $3.8(0.9-9.1)$ & - \\
Pole ash $(\mathrm{n}=3)$ & $57.8(45.0-80.0)$ & $4.4(93.0-6.0)$ & $6.3(4.8-8.9)$ & - \\
Closed-maturing ash $(\mathrm{n}=11)$ & $77.1(70-88.3)$ & $9.0(6.8-11.5)$ & $10.0(7.8-13.85)$ & - \\
Semi mature ash $(\mathrm{n}=10)$ & $75.6(66.7-81.7)$ & $18.8(16.3-22.0)$ & $17.3(15.8-19.7)$ & - \\
Mature ash $(\mathrm{n}=12)$ & $72.2(70-73.3)$ & $21.6(18.5-25.0)$ & $29.1(27.6-30.9)$ & - \\
\hline
\end{tabular}




\section{Sampling protocol}

Pitfalls traps were used to sample spiders across the forest cycle. Each pitfall trap consisted of a plastic cup $(9 \mathrm{~cm}$ depth by $7 \mathrm{~cm}$ diameter) which was sunk flush with the soil surface using a bulb corer. Drainage slits were cut at two locations on the cup, each around $1 \mathrm{~cm}$ from the top. Each trap was filled with ethylene glycol (a killing and preserving agent) to a depth of approximately $2 \mathrm{~cm}$.

Five traps were arranged in $4 \mathrm{~m} \times 4 \mathrm{~m}$ plots, one at each corner and the fifth in the centre of the plot. Each site contained 5 plots which were arranged along a transect, the plots being spaced approximately $50 \mathrm{~m}$ apart. Plot locations were selected to be typical of the forest habitat within the site (i.e. avoiding anomalous features) and were normally a minimum of $50 \mathrm{~m}$ from the forest edge. Due to the small size of some of the ash plantations the number of plots was reduced in the following sites: 2 plots in 4 replicates of the 5 year old ash; 2 plots in 4 replicates of $8-15$ year old ash; 2 plots in 3 replicates and 3 plots in 1 replicate of the $>50$ year old ash. This gave the total number of plots as 120 in Sitka spruce and 60 plots in ash.

Sampling was carried out between June and August 2001, except for the five year old spruce and ash sites which were sampled between June and August 2002. Traps were left in the ground for approximately nine weeks and were emptied three times, giving a total of between 74-75 sampling days per trap.

\section{Environmental variables}

Structural attributes of vegetation were measured using a one metre square quadrat at each trap. Vegetation was classified into ground layer $(<10 \mathrm{~cm})$; lower field layer $(>10 \mathrm{~cm}-50 \mathrm{~cm})$; and upper field layer $(>50 \mathrm{~cm}-200 \mathrm{~cm})$. Other features of the ground cover were also recorded such as twig and soil cover. Percentage cover of each habitat variable was estimated and given a numerical ranking under the BraunBlanquet scale: $+=<1 \%$ cover; $1=1-5 \% ; 2=6-25 \% ; 3=26-50 \% ; 4=51-75 \% ; 5=$ 76 - 100\% (Mueller-Dombois \& Ellenberg, 1974). For the data analysis, the 
appropriate median percent cover value was substituted for the Braun-Blaunquet value taken at each trap and a mean was then calculated for each plot.

At two locations within a plot, litter depth was measured to the nearest $\mathrm{mm}$ and a bulb corer was used to extract the top layer of substrate (both soil and litter) to a depth of $15 \mathrm{~cm}$. Organic content of soil was calculated according to the methodology outlined by Grimshaw (1989). Percentage cover of deadwood within each plot was also estimated. The environmental variables were measured between mid July and mid August for both the 2001 and 2002 field seasons.

\section{Species classification}

A binocular microscope at x 50 magnification was used to identify species and nomenclature follows Roberts (1993). Due to the difficulty involved in identifying juveniles they were excluded from the analyses. The available literature on spiders in Ireland was used to classify specimens into the following habitat preferences: forest or open specialists, or habitat generalists. One species, Lepthyphantes nebulosus was classified as 'other', as it is normally associated with houses and other man made structures. For several species there was insufficient literature available on their ecology in Ireland, so information from UK sources was used (McFerran, 1997; Harvey et al., 2002).

\section{Data Analysis}

Plots were used as the sample unit for all analyses, using combined data from the five pitfall traps within a plot over the three sampling periods.

To identify differences in species richness between the Sitka spruce and ash a twolevel nested design ANOVA was used (Type III sum-of-squares), with structural type as the nested factor within the main factor, canopy species. We used this design, rather than a full factorial design, because structural groups in Sitka spruce and ash are not directly comparable. Patterns in species richness and dominance across structural groups within each canopy species were analysed using One-way 
ANOVA (Type III sum-of-squares) with Tukey HSD (or Kruskal -Wallis test $(\mathrm{H})$, when variances were not homogeneous or the assumptions of normality were not met). Dominance was estimated by calculating the proportion of individuals that the top three most abundant species comprised in each plot, expressed as a percentage. When examining rank abundance plots in most cases three species constituted at least $50 \%$ of the total abundance in the sample plots. These analyses were carried out using SPSS for Windows 11.0.

We used global non-metric multidimensional scaling analysis (NMS) and flexiblebeta cluster analysis (with $\beta=-0.25$ ) for examining assemblage structure. To acquire the best representation of the data in a few dimensions, NMS reflects the similarities (or dissimilarities) between assemblages as accurately as possible (Clarke, 1993). NMS has been successfully applied in several other studies of invertebrates in managed forests (Huhta, 2002; Siira-Pietikainen et al., 2003). The modified Sørensen (also known as Bray \& Curtis) distance measure was used in both NMS and cluster analyses. We used the following parameter protocol for the NMS ordinations: Number of axes $=6$; Runs with real data $=20$; Stability criterion $=0.001$; Iterations to evaluate stability $=10$; Maximum number of iterations $=250$; Step down in dimensionality used; Initial step length $=0.20$; Starting coordinates = Random; Monte Carlo test runs $=50$. We examined the correlations of environmental variables with the ordination axes. These analyses used presence-absence data and were carried out using PC-Ord for Windows Version 4.01.

We used correlation analyses to investigate relationships between species richness and environmental variables within the assemblage groups identified using cluster analysis and NMS ordination. This was done to avoid major differences in assemblage structure within structural groups potentially obscuring relationships between diversity and forest habitat characteristics. Only environmental variables with $n>8$ were used in the correlation analyses for each assemblage group. Bonferroni corrections were not used because when there are a relatively low number of correlations these corrections may cause the significance of real relationships to be lost. Therefore, where we found significant relationships we 
investigated the form of the relationship in more detail, examining the ecological characteristics of the species and sites involved, and significant relationships were viewed with caution if the correlation did not appear to be ecologically meaningful.

We carried out NMS ordination analyses on the habitat variables collected for each plot. The NMS Axis 1 scores of both the species ordination and the habitat variable ordination were correlated. These analyses were carried out using SPSS for Windows 11.0.

\section{Results}

There were a total of 18730 spiders of 139 species collected during the study. Of these species 24 were classified as having a preference for forest habitats and 25 were classified as having a preference for open habitats. 4012 spiders were juveniles and so were excluded from the analyses. A full list of species is given in Appendix 3.

Spider communities across the forest cycle and between canopy species

Species richness

The overall mean species richness differed significantly $\left(\mathrm{F}_{1,170}=13.17, \mathrm{p}=<0.001\right)$ between plots of ash $14.4 \pm(0.75 \mathrm{se})(\mathrm{n}=60)$ and Sitka spruce $16.4 \pm(0.42 \mathrm{se})(\mathrm{n}=120)$. Trends in spider species richness across the forest cycle and between canopy species are shown in Table 2. There was a significant difference in species richness among the Sitka spruce structural groups $(\mathrm{H}=19.34 ; \mathrm{df}=4 ; \mathrm{p}=<0.001)$ with species richness decreasing with the structural development of the stands. Species richness was slightly greater in the mature spruce than the closed maturing and reopening spruce groups. Species richness also declined over the forest cycle in the ash plots with both semi mature and mature ash supporting significantly fewer species than the pre-thicket ash $\left(\mathrm{F}_{4,59}=9.93, \mathrm{p}=0.001\right)$. 
Table 2 Mean species richness of all species, open specialists, forest specialists and mean dominance ( \pm standard error) of spiders in both canopy species across the structural groups ( $\mathrm{n}=$ number of plots).

\begin{tabular}{lcccc}
\hline & $\begin{array}{c}\text { Species } \\
\text { richness }\end{array}$ & $\begin{array}{c}\text { Open species } \\
\text { richness }\end{array}$ & $\begin{array}{c}\text { Forest species } \\
\text { richness }\end{array}$ & Dominance \\
\hline Pre-thicket spruce $(\mathrm{n}=21)$ & $18.6( \pm 1.35)$ & $4.0( \pm 0.46)$ & $1.2( \pm 0.7)$ & $35.8 \%( \pm 2.38)^{\mathrm{b}}$ \\
Thicket spruce $(\mathrm{n}=29)$ & $19.6( \pm 0.78)$ & $1.3( \pm 0.19)$ & $5.9( \pm 0.33)$ & $40.4 \%( \pm 1.45)^{\mathrm{b}}$ \\
Closed-maturing spruce $(\mathrm{n}=35)$ & $14.3( \pm 0.40)$ & $0.2( \pm 0.07)$ & $6.7( \pm 0.21)$ & $47.3 \%( \pm 1.75)$ \\
Reopening spruce $(\mathrm{n}=10)$ & $14.5( \pm 0.79)$ & $0.1( \pm 0.10)$ & $7.6(0.54)$ & $52.2 \%( \pm 2.94)$ \\
Mature spruce $(\mathrm{n}=25)$ & $16.7( \pm 0.98)$ & $0.9( \pm 0.20)$ & $7.1( \pm 0.20)$ & $52.3 \%( \pm 2.24)^{\mathrm{a}}$ \\
\hline Pre-thicket ash $(\mathrm{n}=24)$ & $18.1( \pm 0.86)^{\mathrm{a}}$ & $4.8( \pm 0.28)^{\mathrm{a}}$ & $1.7( \pm 0.24)$ & $36.6 \%( \pm 2.41)^{\mathrm{b}}$ \\
Pole ash $(\mathrm{n}=3)$ & $14.2( \pm 3.28)$ & $2.0( \pm 0.58)^{\mathrm{b}}$ & $2.3( \pm 1.45)$ & $51.2 \%( \pm 7.61)^{\mathrm{b}}$ \\
Closed-maturing ash $(\mathrm{n}=11)$ & $17.4( \pm 1.87)$ & $3.3( \pm 0.49)^{\mathrm{b}, \mathrm{c}}$ & $3.3( \pm 0.69)$ & $37.2 \%( \pm 3.14)^{\mathrm{a}}$ \\
Semi mature ash $(\mathrm{n}=10)$ & $10.8( \pm 0.95)^{\mathrm{b}}$ & $0.5( \pm 0.27)^{\mathrm{b}, \mathrm{d}}$ & $5.4( \pm 0.43)$ & $62.1 \%( \pm 4.12)$ \\
Mature ash $(\mathrm{n}=12)$ & $10.0( \pm 1.38)^{\mathrm{b}}$ & $0.9( \pm 0.26)^{\mathrm{b}, \mathrm{d}}$ & $5.0( \pm 0.56)$ & $57.3 \%( \pm 7.80)^{\mathrm{a}}$ \\
\hline
\end{tabular}

a This species variable is significantly greater than the values marked with ${ }^{b}$ within that canopy species.

c This species variable is significantly greater than the values marked with ${ }^{\mathrm{d}}$ within that canopy species. 
Overall there were significantly more forest species found in the Sitka spruce plots (F $1,170=48.20, \mathrm{p}=<0.001)$, and significantly more open species in the ash plots $\left(\mathrm{F}_{1,170}\right.$ $=40.85, \mathrm{p}=<0.001)$ (Table 2). In general open species richness declines over the forest cycle in both canopy species, the pre-thicket plots of both ash and spruce supporting significantly higher numbers of open species than the more mature plots ( $F$ 4,59 $=29.78, \mathrm{p}=<0.001$ and $\mathrm{H}=68.34 ; \mathrm{df}=4 ; \mathrm{p}=<0.001$ respectively). However there is a slight increase in open specialists towards the end of the forest cycle in spruce plots. There was a significant difference in the number of forest species located among the spruce and the ash structural groups $(\mathrm{H}=61.62 ; \mathrm{df}=4 ; \mathrm{p}=<$ 0.001 and $\mathrm{H}=68.34 ; \mathrm{df}=4 ; \mathrm{p}=<0.001$ respectively). In both the ash and Sitka spruce stands there was a higher number of forest specialists found in the more mature plots.

\section{Dominance}

Mean dominance differed significantly between ash $(0.60, \pm 0.02$ se) and spruce $(0.57$, \pm 0.009 se $)$ plots $\left(\mathrm{F}_{1,170}=8.19, \mathrm{p}=<0.001\right)$. The less well-developed structural groups of both canopy species exhibit similar levels of dominance, however dominance is greater in the mature ash than in the mature spruce structural groups (Table 2). In general dominance increases over the forest cycle in both spruce and ash plots (Table 2). The pre-thicket and thicket spruce plots have significantly lower dominance than the more mature spruce plots $\left(\mathrm{F}_{4,119}=5.22, \mathrm{p}=<0.001\right)$, and the pre-thicket and closed-maturing ash structural groups have significantly lower dominance than pole ash and the more mature ash groups $\left(\mathrm{F}_{4,59}=8.78, \mathrm{p}=<0.001\right)$.

Assemblage structure

The first two NMS ordination axes explained $82 \%$ of the variation in spider assemblages (Figure 2). The plots were separated by both structural development and canopy openness along Axis 1, with the more structurally developed plots negatively correlated with this axis. The thicket, closed-maturing, reopening and mature spruce tended to form a tightly clustered group, although some of the thicket and mature spruce plots separate out along Axis 1, according to structural development and canopy openness. 


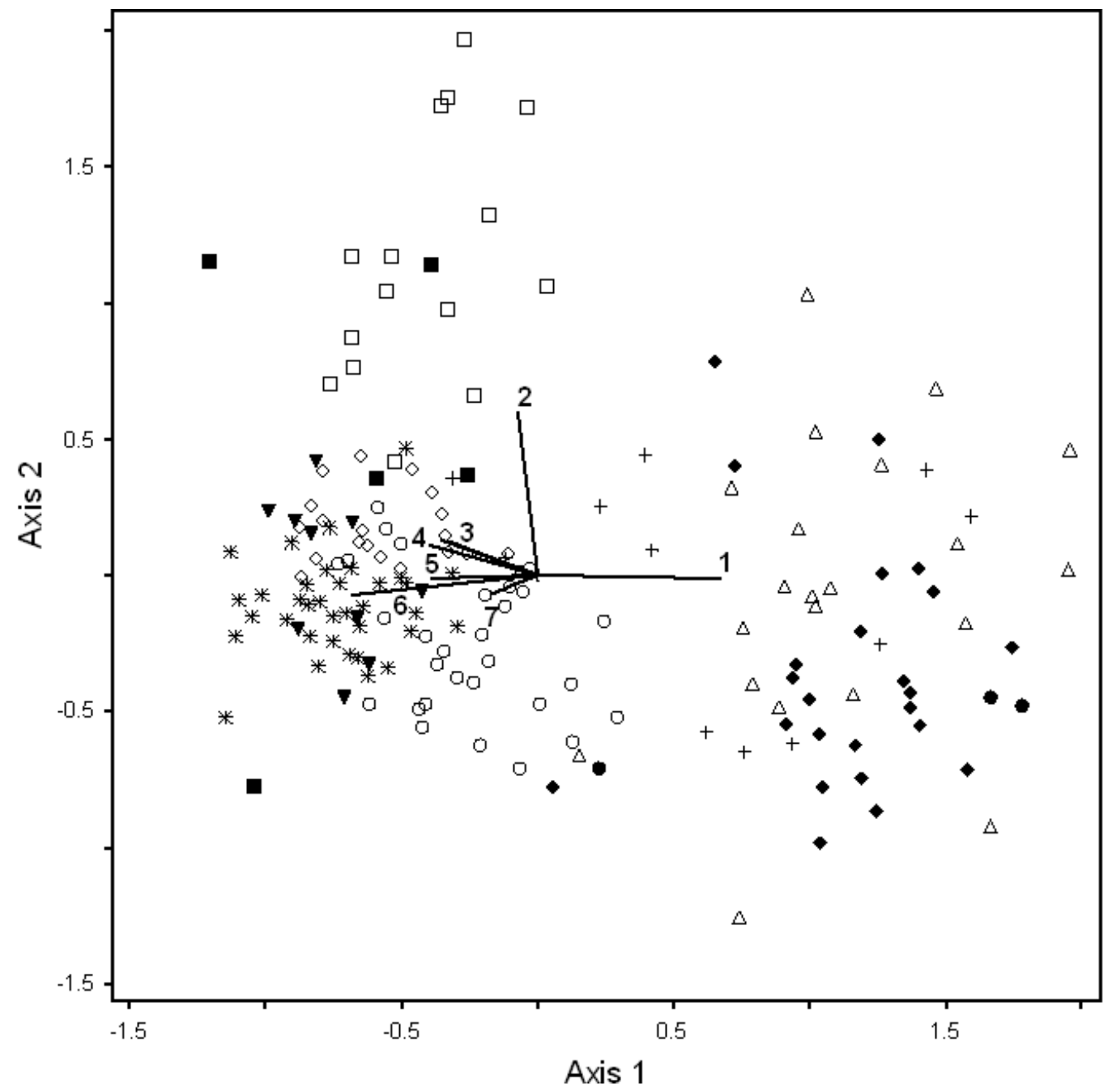

Figure 2 NMS ordination of plots with species data across structural groups. Axis one, $r^{2}=0.61$; Axis two, $r^{2}=0.21$. Final stress for a 2-D solution $=20.54$, final instability $=0.00044$.. Structural groups: $+=$ Pre- thicket spruce; $)=$ Thicket spruce; $\mathrm{H}$ = Closed-maturing spruce; $\&=$ Reopening spruce; ( = Mature spruce; $\forall=$ Prethicket ash; \# = Pole ash; + = Closed-maturing ash; э = Semi-mature ash; ! = Mature ash.. Environmental variables: 1 = Lower field layer cover; $2=$ Leaf litter cover; 3 = Deadwood/Twig cover; $4=$ ground vegetation cover; $5=$ Litter depth; $6=$ Needle litter cover; 7 = Organic content

Axis 1 is positively correlated with environmental variables associated with more open plots, such as lower and upper field layer cover (0), and negatively correlated 
with forest-related variables such as twig cover, deadwood, ground vegetation and litter depth. This may explain the separation of species assemblages in the younger, more open plots from those in the more mature plots (Figure 2). The spider assemblages of the mature ash plots are separated from the mature spruce across Axis 2 which is most notably positively correlated with leaf litter cover. The distinction between the less well developed spruce and ash plots across both axes is less well pronounced.

Cluster analysis identified five main groups of spider assemblages (Table 3). Figure 3 superimposes the assemblages on the ordination of species data (0) and confirms the division of spider assemblages is into five main assemblage groups in relation to the forest environment. The young spruce/ash group, young ash group and mature ash group are generally internally consistent in terms of forest type plots (Table 3), whereas the closed canopy spruce and open spruce groups encompass a somewhat more variable range of structural groups separated on the basis of canopy development.

Table 3 The distribution of plots within the assemblage groups identified by cluster analysis.

\begin{tabular}{lccccc}
\hline Structural group & \multicolumn{5}{c}{ Assemblage group } \\
\cline { 2 - 6 } & $\begin{array}{c}\text { Young } \\
\text { spruce/ } \\
\text { ash } \\
(\mathrm{n}=20)\end{array}$ & $\begin{array}{c}\text { Young } \\
\text { ash } \\
(\mathrm{n}=34)\end{array}$ & $\begin{array}{c}\text { Mature } \\
\text { Ash } \\
(\mathrm{n}=16)\end{array}$ & $\begin{array}{c}\text { Closed- } \\
\text { canopy } \\
\text { spruce } \\
(\mathrm{n}=59)\end{array}$ & $\begin{array}{c}\text { Open } \\
\text { spruce } \\
(\mathrm{n}=44)\end{array}$ \\
$\begin{array}{l}\text { Pre-thicket spruce } \\
\text { Thicket spruce }\end{array}$ & 8 & & 8 & 1 \\
Closed-maturing spruce & & & & 31 & 21 \\
$\begin{array}{l}\text { Reopening spruce } \\
\text { Mature spruce }\end{array}$ & & & 9 & 4 \\
Pre-thicket ash & 4 & 19 & & 9 & 11 \\
$\begin{array}{l}\text { Pole ash } \\
\text { Closed-maturing ash }\end{array}$ & 2 & 1 & & & 1 \\
Semi mature ash & 2 & 6 & & & 3 \\
Mature ash & & & 8 & 2 & 2 \\
\hline
\end{tabular}




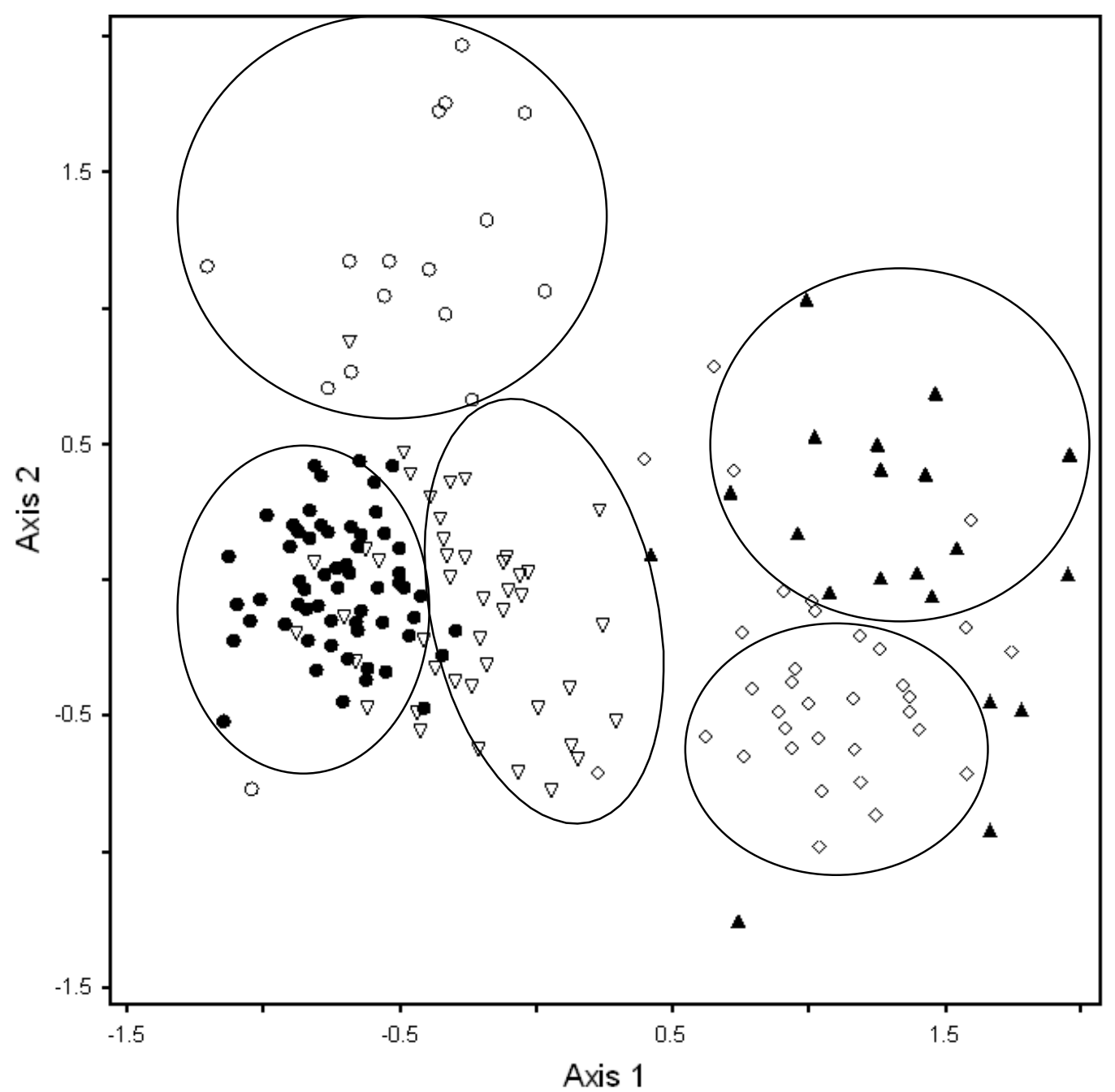

Figure 3 NMS ordination of plots with species data across assemblage groups. $\mathrm{r}^{2}$ values and NMS parameters as Figure 2. \%= Young spruce/ash; $(=$ Young ash; $)=$ Mature ash; \# = Closed canopy spruce; ,= Open spruce. 
Relationships between spider assemblage groups and environmental variables

NMS ordination of plots using the environmental variables explains $82 \%$ of the variation across the plots. The Axis 1 scores of both the ordination of plots using environmental variables and of plots using species data (Figure 2) are significantly positively correlated $(\mathrm{r}=0.66 ; \mathrm{df}=175 ; \mathrm{p}=<0.001)$.

Species richness is positively correlated with lower field layer vegetation in the less structurally developed assemblage groups of young spruce/ash $(\mathrm{p}=<0.05)$ and young ash $(\mathrm{p}=<0.05)(0)$. There is also a positive, but non-significant association between species richness and lower field layer vegetation in the open spruce group. Species richness is negatively correlated with forest-associated variables such as deadwood $(\mathrm{p}=<0.01)$ and twig cover, in the young ash group. There is a negative relationship between species richness and soil cover in this group $(\mathrm{p}=<0.05)$, and also in the mature ash group $(\mathrm{p}=<0.05)$. Total species richness and organic content have a strong positive correlation in the young spruce/ash group $(\mathrm{p}=<0.01)$.

In the young ash assemblage group, open species richness is significantly negatively correlated with forest-associated variables such as dead wood $(p=<0.01)$ and soil cover $(p=<0.01)(0)$. This group also shows a negative, but non-significant association with twig cover. In the young spruce/ash group, open species richness is positively correlated with ground vegetation $(\mathrm{p}=<0.05)$, whereas in the open spruce group these variables are significantly negatively correlated $(p=<0.01)$. In the closed canopy spruce group open species richness is negatively correlated with canopy cover $(p=<0.05)$. Forest species richness is positively correlated with ground vegetation and factors associated with forests such as twig and deadwood cover. Forest species are significantly negatively correlated with factors associated with open areas (i.e. lower and upper field layer cover) in the more mature groups. 
Table 4 Pearson correlations (r) of species richness and environmental variables across assemblage groups. Only correlations with $\mathrm{p}=<0.01$ are included.

\begin{tabular}{|c|c|c|c|c|c|}
\hline $\begin{array}{c}\text { Environmental } \\
\text { variable }\end{array}$ & $\begin{array}{c}\text { Young } \\
\text { spruce/ } \\
\text { ash } \\
(\mathrm{n}=20)\end{array}$ & $\begin{array}{c}\text { Young } \\
\text { ash } \\
(\mathrm{n}=34)\end{array}$ & $\begin{array}{c}\text { Mature } \\
\text { ash } \\
(\mathrm{n}=16)\end{array}$ & $\begin{array}{l}\text { Closed- } \\
\text { canopy } \\
\text { spruce } \\
(n=59)\end{array}$ & $\begin{array}{c}\text { Open } \\
\text { spruce } \\
(\mathrm{n}=44)\end{array}$ \\
\hline \multicolumn{6}{|l|}{ All species } \\
\hline Organic content & $0.57^{* *}$ & & & & \\
\hline Lower field layer & $0.45^{*}$ & $0.40^{*}$ & & & 0.26 \\
\hline Dead wood cover & & $-0.50^{* *}$ & & & \\
\hline Soil cover & & $-0.33^{*}$ & $-0.47^{*}$ & & \\
\hline Twig cover & & -0.30 & & & \\
\hline \multicolumn{6}{|c|}{ Open habitat specialists } \\
\hline Ground vegetation & $0.62^{* *}$ & & & & $-0.32^{*}$ \\
\hline Organic content & & & & & $-0.35^{*}$ \\
\hline Dead wood cover & & $-0.47^{* *}$ & & & \\
\hline Twig cover & & -0.32 & & & \\
\hline Canopy cover & & & & $-0.31^{*}$ & \\
\hline Soil cover & & $-0.47^{* *}$ & & & \\
\hline \multicolumn{6}{|c|}{ Forest habitat specialists } \\
\hline Leaf litter cover & & $0.54^{* * *}$ & & & \\
\hline Lower field layer & & & $-0.58^{*}$ & & \\
\hline Ground vegetation & & $0.36^{*}$ & & & $0.45^{* *}$ \\
\hline Soil cover & & $0.45^{* *}$ & & & \\
\hline Upper field layer & & -0.32 & & $-0.27^{*}$ & $-0.48^{* * *}$ \\
\hline Twig cover & & $0.34^{*}$ & & & $0.46^{* *}$ \\
\hline Dead wood cover & & & & & 0.27 \\
\hline
\end{tabular}

Only correlations with $\mathrm{p}=<0.01$ are included. $\mathrm{p}>0.05$ to $<0.1$ : no symbol.

$$
\begin{aligned}
& * \quad p<0.05 \\
& * * \quad p<0.01 \\
& * * * \quad p<0.001
\end{aligned}
$$




\section{Discussion}

Pitfall traps sample a high number of species (Curtis, 1980) and their efficiency can be easily measured by the number of traps set and the duration of trapping. However the results derived from pitfall traps must be treated with caution, as catches can only be reliably compared if species activity, species behaviour and species density remain constant across study areas (Downie et al., 1996). The vegetation structure surrounding a pitfall trap has a negative effect on the capture rate of invertebrates, and where this varies among sample points the interpretation of absolute abundance data is problematic (Melbourne, 1999), hence it was considered more appropriate to use either species presence-absence data or relative abundance data in this study. The findings of this study can only relate to active ground dwelling spiders and the results were interpreted in this light.

Plots within the pre-thicket structural groups were sampled over two years, however this was not found to affect either species richness or assemblage structure. Temporal variation has been found to have a greater effect on spider abundance, than either species richness or assemblage structure (Cameron et al., 2004). Therefore, as absolute abundance data was not used in these analyses it was felt that temporal variation had a minimal effect.

Spider communities over the forest cycle and between canopy species.

In the present study spider assemblages were found to vary in relation to both structural development and canopy species across the forest cycle. Although coniferous plantations are generally thought of as an inferior habitat for wildlife (Newton \& Humphrey, 1997), these results suggest that in terms of stand biodiversity, Sitka spruce is able to support a wide array of spider species. Mature spruce plantations have been found to contain comparable numbers of fungal species to a semi natural Scots pine forest (Newton \& Humphrey, 1997) and Humphrey et al. (1999) showed that pine plantations supported a diversity of carabids and syrphids similar to those found in semi-natural woodlands. However in a comparative study of Irish forests Fahy and Gormally (1998) found that a semi- 
natural oak woodland supported a far greater number of carabid species than a conifer plantation.

In the present study the mature ash stands supported fewer spider species than mature spruce. A review of biodiversity in Scottish native woodlands found that native pine species contained $66 \%$ more species of herbivorous insects and almost double the number of species of ectomycorrhizal fungi than native ash, and that in general ash has a lower invertebrate diversity than other native broadleaves (Newton \& Humphrey, 1997). This suggests that low species diversity may be a feature of ash forests whether planted or natural.

Pre-thicket stands

Spider assemblages in the pre-thicket stands, of both ash and Sitka spruce, are distinct from those in the mature stands, being more typical of open habitats. These stands exhibited high spider species richness and open habitat species richness as well as low dominance (as found by Pajunen et al., 1995) as well as the greatest cover of lower field layer vegetation. The vegetation of the pre-thicket plots was dominated by species typical of open habitats and was generally taller, and probably more structurally diverse, than in the more mature plots.

Habitat structure can directly influence the ability of spiders to perceive their environment as they primarily use vibratory cues for prey location and determining the physical organisation of the environment (Uetz, 1991). Active hunters (non-web builders) utilise aspects of the habitats' architecture for concealment and creating preferential positions for prey location (Uetz, 1991). Habitat structure can also provide protection from predators (Gunnarsson, 1996). This is particularly important for the larger active hunters (such as Lycosids and Clubionids), which may be at greater risk of predation from birds (Askenmo et al., 1977). In the present study, the pre-thicket plots supported the largest numbers of these species.

Structural heterogeneity may also influence spider communities indirectly by positively affecting on prey densities; typical prey species such as herbivorous invertebrates (Nentwig, 1980) benefit from the greater variety of food resources available in more structurally diverse habitats (Siira-Pietikainen et al., 2003). 
Structural complexity also provides more web attachment points (Uetz, 1991). Although pitfall traps will not efficiently sample web spinners which inhabit the upper vegetation layers, other web spinners, such as those from the family Linyphiidae, can be adequately sampled (Standen, 2000). These species generally live close to the ground and utilise structural aspects of the habitat including vegetation, stones and litter layers on which to attach their sheet webs (Roberts, 1993).

Although pre-thicket plots were not separated on the basis of their pre-planting habitat type per se, there was a broad division between pre-thicket spruce and ash stands (0). Floristic differences between pre-planting habitats, which may persist up to and beyond canopy closure, are of little consequence to spider communities compared to vegetation structure (Clausen, 1986). General differences in the type of habitats which are commonly used for planting ash and spruce may account for these community differences. Ash is more typically planted on wetter, lowland areas with richer soils whereas spruce is more commonly planted in upland areas (Gittings et al., 2004).

Canopy closure

The effect of canopy closure on spider species richness was much more apparent in the denser canopy Sitka spruce, where the lower field layer vegetation cover decreased to a much greater degree than in the mature ash plots. In the present study the ground cover in the closed canopy spruce plots was very homogenous, characterised by a lack of vegetation cover at all under-storey structural levels, and a high coverage of needle litter. Canopy closure reduces the number of open specialist spider species which are probably reliant on the plants associated with the preplanting habitat. Canopy closure has been found to have profound effects on carabids and syrphids, which are probably also responding to the reduction in vegetation structure or diversity (Humphrey et al., 1999).

In contrast the forest specialists benefit from the habitat conditions created by canopy closure. The positive relationship between forest litter layers and spider diversity has been well documented, (Uetz, 1975, 1979), the litter layers adding 
habitat architecture to the forest floor and enhancing prey species diversity (Uetz, 1979). Many litter-dwelling invertebrate species are consumed by spiders (Moulder \& Reichle, 1972). For instance, Collembola are important prey for the Linyphiidae spider family (Nyfeller \& Sunderland, 2003), which constituted 96\% of all spiders found within the mature spruce structural groups.

Ground vegetation which is more typical of a forest environment (Ferris \& Humphrey, 1999), increases during the forest cycle and probably benefits from the negative effect of shading on lower field layer species. The forest spider species identified were mostly ground dwellers, which are more likely to utilise ground vegetation. Watt et al (1997) also found a negative effect of canopy closure on plant communities in spruce forests. However they did observe a high diversity and abundance of soil dwelling invertebrates such as Hymenoptera, Collembola and Acarina. These species are known to flourish in the dark and damp conditions associated with closed canopy spruce (Newton \& Humphrey, 1997) and are possibly utilised as prey by forest specialists.

Mature stands

The species assemblages of some mature spruce plots are more similar to those thicket spruce plots which have not completely achieved canopy closure than to those of closed canopy spruce. The mature spruce plots are more open (due to successive canopy thinnings) and therefore have a more complex vegetation structure (Ferris et al., 2000). This assemblage group has the highest overall spider species richness, presumably because the presence of the lower field layer allows open habitat species to coexist with forest habitat species which are still present in the more shaded areas.

Canopy species has a stronger effect on spider communities in the mature stands than in the less well-developed stands. Mature ash plots are distinct from the other plots in their assemblage structure, their low species richness and their high dominance. The ground and lower field vegetation layers in the mature ash plots were nearly all composed of ivy (Hedera helix), whereas in the more mature spruce plots the grasses, ferns and brambles provide a greater structural complexity to the 
lower field layer (personal observation). This may explain why forest species are negatively correlated with lower field layer in mature ash plots. A more detailed assessment of the structural diversity of the vegetation may be needed in the mature ash stands to interpret the low species richness and distinction of spider assemblages they support. Although the highest leaf litter cover was recorded in mature ash, litter depth was considerably lower than in the mature spruce. Consequently, the lack of structure in the leaf litter which is likely to have a negative effect on species richness (Uetz, 1979), may also explain the distinctiveness of the community structure.

\section{Structural Indicators of spider diversity}

These results suggest that the structure of the lower vegetation layers (in terms of percentage cover) and the forest stand (the degree of canopy openness) are major factors affecting spider assemblages and potential structural indicators of spider diversity. The lower field layer is an important determinant of total and open specialist spider species richness. Stands with a more open canopy and hence a high cover of field layer vegetation are also known to positively affect ground beetle diversity (Day et al., 1993; Fahy \& Gormally, 1998) and understorey development (Ferris et al., 2000) In forests. In terms of forest management, multiple thinnings (and hence gap creation) are likely to have a substantial positive affects on spider species diversity. These gaps should be maintained throughout the forest cycle as the vegetation structure will not be retained if canopy closure resumes (Alaback \& Herman, 1988).

Forest spider species are positively correlated with ground vegetation cover, heavy canopy cover and a dense upper field layer which decreases light levels within a forest. In contrast, ivy, which is a typical forest vegetation species, may be an indicator of low species richness, as is suggested by the mature ash stands. Forest specialists also benefit from high litter cover and deep litter layer, as found in the mature spruce plots. However these variables are indicators of lower overall species richness within the various assemblage groups. 


\section{Conclusions}

Managing habitats for maximum species richness or diversity with no consideration of assemblage structure or specialists present, can lead to the loss of important biological information (Lindenmayer, 1999). For example, although forest specialists are not indicative of overall species richness, they are nevertheless an important component of the Irish spider fauna. The paucity of natural woodlands in Ireland (Coillte, 2003) means that plantations could be a potentially important habitat for these specialists.

Forest managers should encourage the growth of lower field layer vegetation species at all stages of the forest cycle, whilst retaining features typical of a mature forest in order to enhance the diversity of both open and forest species within a plantation. At a landscape scale, a mosaic of different aged plantations will provide the heterogeneity of habitat types necessary to sustain both open and forest specialists. The distinctiveness of the spider assemblages in the mature ash stands suggests that establishing several canopy species (both coniferous and broad leaves) in a plantation will also enhance overall landscape biodiversity.

In the past the inclusion of invertebrates in sustainable forest management schemes may have been neglected. Indeed, the current forest biodiversity guidelines for Ireland (Forest Service, 2000) make no explicit mention of invertebrates. When considering the implications of managing forests for biodiversity, establishing a set of easily recognisable and quantifiable structural indicators is vitally important. This study has shown that there may be straightforward ways to enhance spider diversity which correspond with the management of other invertebrate groups and plants. Indicators such as cover of field layer vegetation, canopy and litter layers could be assessed by foresters with little or no specialist taxonomic training making it possible for spiders to be incorporated into sustainable forest management strategies. 


\section{References}

Alaback, P.B. \& Herman, F.R., 1988. Long-term response of understorey vegetation to stand density in Picea-Tsuga forests. Canadian. J. For. Res. 18, 1522-1530.

Askenmo, C., von Brömssen, A., Ekman, J., \& Jansson, C., 1977. Impact of some wintering birds on spider abundance in spruce. Oikos. 28, 90-94.

Cameron, A., Johnston, R.J., McAdam, J., 2004. Classification and evaluation of spider assemblages on environmentally sensitive areas in Northern Ireland. Agri. Ecosys. Environ. 102, 29-40.

Clarke, K.R., 1993. Non-parametric multivariate analyses of changes in community structure. Australian J. Ecol. 18, 117-143.

Coillte 2003. : \\www.coillte.ie \managing_our_forests.htm. Coillte Teoranta.

Curtis, D.J., 1980. Pitfalls in spider community studies (Arachnida: Araneae). J. Arachnol. 8, 271-280.

Day, K.R., Marshall, S., \& Heaney, C., 1993. Associations between forest type and invertebrates: Ground beetle community patterns in a natural oak wood and juxtaposed coniferous plantations. Forestry. 66, 37-50.

Downie, I., Coulson, J., \& Butterfield, J., 1996. Distribution and dynamics of surface dwelling spiders across a pasture - plantation ecotone. Ecography. 19, 29-40.

Duelli, P. \& Obrist, M.K., 2003. Biodiversity indicators: the choice of values and measures. Agri. Ecosys. Environ. 98, 87-98.

Fahy, O. \& Foley, N., 2002. Biodiversity opportunities in plantations managed for wood supply. In L. MacLennan (ed). Opportunities for biodiversity enhancement in plantation forests. COFORD. Cork, Ireland.

Fahy, O. \& Gormally, M., 1998. A comparison of plant and carabid communities in an Irish oak woodland with a nearby conifer plantation and a clearfelled site. For. Ecol. Manage. 110, 263-273.

Ferris, R. \& Humphrey, J.W., 1999. A review of potential biodiversity indicators for application in British forests. Forestry. 72, 313-328.

Ferris, R., Peace, A.J., Humphrey, J.W., \& Broome, A.C., 2000. Relationships between vegetation, site type and stand structure in coniferous plantations in Britain. For. Ecol. Manage. 136, 35-51. 
Forest Service, 2000. Forest Biodiversity Guidelines. Forest Service, Department of the Marine and Natural resources, Dublin.

Gittings, T., Smith, G., Wilson, M., French, L., Oxbrough, A., O'Donoghue, S., Pithon, J., O'Donnell, V., McKee, A., Iremonger, S., O'Halloran, J., Kelly, D., Mitchell, F., \& Giller, P., 2004. Assessment of Biodiversity at different stages of the forest cycle. Unpublished report prepared for COFORD and EPA.

Gravesen, E., 2000. Spiders (Araneae) and other invertebrate groups as ecological indicators in wetland areas. Ekologia (Bratislava). 19, 39-42.

Grimshaw, H.M., 1989. Analysis of soils. In: Grimshaw H.M. (Eds), Chemical analysis of ecological materials. Blackwell Scientific Publications, Oxford, pp. $14-16$.

Gunnarsson, B., 1996. Bird predation and vegetation structure affecting spruce-living arthropods in a temperate forest. J. Anim. Ecol. 65, 389-397.

Haila, Y., Hanski, I., Niemelä , J., Punttila, P., Raivio, S., \& Tukia, H., 1994. Forestry and the boreal fauna: matching management with natural forest dynamics. Ann. Zool. Fenn. 31, 187-202.

Halaj, J., Ross, R., \& Moldenke, R., 2000. Importance of habitat structure to the arthropod food-web in Douglas-fir canopies. Oikos. 90, 139-152.

Harvey, P., Nellist, D., \& Telfer, M. (2002). Provisional Atlas of British spiders (Arachnida, Araneae), Volume $1 \& 2$. Biological Records Centre, Huntingdon.

Huhta, V., 2002. Soil macroarthropod communities in planted birch stands in comparison with natural forests in central Finland. Appl. Soil. Ecol. 20, 199-209. Humphrey, J., Davey, S., Peace, A., Ferris, R., \& Harding, K., 2002. Lichens and bryophyte communities of planted and semi-natural forests in Britain: the influence of site type, stand structure and deadwood. Biol. Conserv. 107, 165180.

Humphrey, J., Hawes, C., Pearce, A., Ferris-Kaan, R., \& Jukes, M., 1999.

Relationships between insect diversity and habitat characteristics in plantation forests. For. Ecol. Manage. . 113, 11-21.

Joyce, P. \& O'Carroll, N. (2002) Sitka spruce in Ireland. COFORD National council for forest research and development, Dublin. 
Jukes, M., Peace, A., \& Ferris, R., 2001. Carabid beetle communities associated with coniferous plantations in Britiain: the influence of site, ground vegetation and stand structure. For. Ecol. Manage. 148, 271-286.

Legendre, P. \& Legendre, L. (1998). Numerical Ecology, Second English Edn. Elsevier, Amsterdam.

Lindenmayer, D., 1999. Future directions for biodiversity conservation in managed forests: indicator species, impact studies and monitoring programs. For. Ecol. Manage. 115, 277-287.

Marc, P., Canard, A., \& Ysnel, F., 1999. Spiders (Araneae) useful for pest limitation and bioindication. Agri. Ecosys. Environ. 74, 229-273.

McFerran, D., 1997. Northern Ireland Species Inventory Spiders (Arachnida). Queens University Belfast, Belfast.

McGeoch, M., 1998. The selection, testing and application of terrestrial insects as bioindicators. Biol. Revs. 73, 181-201.

Melbourne, B., 1999. Bias in the effect of habitat structure on pitfall traps: An experimental evaluation. Australian J. Ecol. 24, 228-239.

Moulder, B. \& Reichle, D., 1972. Significance of spider predation in the energy dynamics of forest-floor arthropod communities. Ecol. Mono. 42, 473-498.

Mueller-Dombois, D. \& Ellenberg, H. (1974) Aims and methods of vegetation ecology Wiley and sons, New York.

Nentwig, W., 1980. The selective prey of Linyphiid - like spiders and of their space webs. Oecologia. 45, 236-243.

Newton, A. \& Humphrey, J., 1997. Forest management for biodiversity: perspectives on the policy context and current initiatives. In: Fleming ,V., Newton, A., Vickery, J., \& Usher ,M. (Eds), Biodiversity in Scotland: status, trends and initiatives. Scottish National Heritage Council, Edinburgh.

Noss, R.F., 1990. Indicators for Monitoring Biodiversity - a Hierarchical Approach. Conserv. Biol. 4, 355-364.

Nyfeller, M. \& Sunderland, K., 2003. Composition, abundance and pest control potential of spider communities in agroecosystems: a comparison of European and US studies. Agri. Ecosys. Environ. 95, 579-612. 
Oliver, I., Mac Nally, R., \& York, A., 2000. Identifying performance indicators of the effects of forest management on ground-active arthropod biodiversity using hierarchical partitioning and partial canonical correspondence analysis. For. Ecol. Manage. 139, 21-40.

Pajunen, T., Haila, Y., Halme, E., Niemela, J., \& Punttila, P., 1995. Ground-dwelling spiders (Arachnida, Araneae) in fragmented old forests and surrounding managed forests in southern Finland. Ecography. 18, 62-72

Pettersson, R., 1996. Effect of forestry on the abundance and diversity of arboreal spiders in the boreal spruce forest. Ecography. 19, 221-228.

Roberts, M. (1993) The spiders of Great Britain and Ireland. Part One, Compact Edition edn. Harley Books, Colchester.

Siira-Pietikäinen, A., Haimi, J., \& Siitonen, J., 2003. Short-term responses of soil macroarthropod community to clear felling and alternative forest regeneration methods. For. Ecol. Manage. 172, 339-353.

Standen, V., 2000. The adequacy of collecting techniques for estimating species richness of grassland invertebrates. Journal of Applied Ecology. 37, 884-893.

Uetz, G., 1979. The influence of variation in litter habitats on spider communities. Oecologia. 40, 29-42.

Uetz, G., 1991. Habitat structure and spider foraging. In: Bell, S., McCoy, E., \& Mushinsky, H., Habitat structure: The physical arrangement of objects in space. Chapman and Hall, London.

Watt, A., Barbour, D., \& McBeath, C., 1997. The invertebrate fauna associated with birch in spruce forests. Scottish National Heritage Research, Survey and Monitoring Report No. 82.

Willet, T. R., 2001. Spiders and other arthropods as indicators in old-growth versus logged redwood stands. Restoration Ecology. 9, 410-420. 